\title{
Antibody Cross-Linking of Myelin Oligodendrocyte Glycoprotein Leads to Its Rapid Repartitioning into Detergent-Insoluble Fractions, and Altered Protein Phosphorylation and Cell Morphology
}

\author{
C. B. Marta, C. M. Taylor, T. Coetzee, T. Kim, S. Winkler, R. Bansal, and S. E. Pfeiffer \\ Department of Neuroscience, University of Connecticut Medical School, Farmington, Connecticut 06030-3401
}

\begin{abstract}
Myelin oligodendrocyte glycoprotein (MOG) is, quantitatively, a relatively minor component of the myelin membrane. Nevertheless, peritoneal administration of MOG evokes potent cellular and humoral immunoreactivity, resulting in an experimental allergic encephalitis with immunopathology similar to multiple sclerosis. Moreover, antibodies against MOG cause myelin destruction in situ. Therefore, it appears that MOG-related demyelination is dependent on anti-MOG antibody, but the mechanism(s) by which it occurs is unclear. Of potential significance are observations that some proteins are selectively partitioned into specialized plasma membrane microdomains rich in glycosphingolipids and cholesterol ("lipid rafts"). In particular, during ligand or antibody cross-linking, various plasma membrane receptors undergo enhanced partitioning into rafts as an obligatory first step toward participation in early signal transduction events. In contrast to mature myelin, in oligodendrocytes (OLs) in culture MOG is not raft associated [Triton X-100 (TX-100) soluble, $4^{\circ} \mathrm{C}$ ]. However, in this study we show that antibody cross-linking (anti-MOG plus secondary antibody) of MOG on the surface of OLs results in the repartitioning of $\sim 95 \%$ of MOG into the TX-100-insoluble fraction. This repartitioning of MOG is rapid ( $\leq 1 \mathrm{~min}$ ), antibody dose dependent, requires an intact cytoskeleton, leads to phosphorylation or dephosphorylation of tyrosine, serine, and threonine residues in specific proteins (e.g., $\beta$-tubulin, $\mathrm{G} \beta_{1-2}$ ), and invokes a rapid retraction of $\mathrm{OL}$ processes. After removal of the cross-linking antibodies, these events are reversed. We hypothesize that antibody-mediated repartitioning of MOG into TX-100-insoluble glycosphingolipidcholesterol-rich microdomains initiates specific cellular signaling that could be related to initial steps of MOG-mediated demyelination.
\end{abstract}

Key words: myelin oligodendrocyte glycoprotein; oligodendrocytes; multiple sclerosis; lipid rafts; cytoskeleton; signaling

\section{Introduction}

Myelin is a unique, lipid-rich biological membrane produced in the CNS by oligodendrocytes (OLs) (Pfeiffer et al., 1993; Madison et al., 1999). Loss or damage of this functionally active membrane results in neurological deficits such as occur in multiple sclerosis (MS). Myelin oligodendrocyte glycoprotein (MOG) is an integral myelin membrane protein present primarily in the outer lamella of the myelin sheath. Despite its relatively low abundance (0.01$0.05 \%$ of the total myelin protein), it has been implicated as a potentially major player in demyelinating diseases (Linington et al., 1984).

Besides inflammatory mediators derived from $\mathrm{T}$ cells, there is increasing evidence that anti-MOG effector mechanisms play an important role in the pathogenesis of demyelination (Reindl et al., 1999; Iglesias et al., 2001; Von Büdingen et al., 2001). Anti-

Received Jan. 10, 2003; revised March 14, 2003; accepted April 11, 2003.

This work was supported by National Institutes of Health Grants NS10861 and NS41078 and in part by a Postdoctoral Fellowship from the National Multiple Sclerosis Society. We thank Dr. Christopher Linington for providing anti-MOG antibody and for fruitful discussions. We are pleased to acknowledge the excellent administrative support of Wendy Wolcott, Janice Seagren, and Jennifer Gilman.

Correspondence should be addressed to Cecilia Marta, Department of Neuroscience, University of Connecticut Medical School, 263 Farmington Avenue, Farmington, CT 06030-3401. E-mail: Marta@up.uchc.edu.

Copyright $\odot 2003$ Society for Neuroscience $\quad$ 0270-6474/03/235461-11\$15.00/0
MOG antibodies are found in the CSF and in disintegrating myelin around axons in lesions of acute MS patients (Linington and Lassmann, 1987; Xiao et al., 1991; Genain et al., 1995; Reindl et al., 1999). Presentation of purified MOG induces severe demyelinating experimental allergic encephalomyelitis (EAE) in both rodents and primates (Johns and Bernard, 1999; Iglesias et al., 2001). When a monoclonal antibody (mAb) against MOG is injected into rodents, there is extensive demyelination (Schluesener et al., 1987; Linington et al., 1988). In addition, demyelination was produced in aggregating brain cell cultures by anti-MOG, whereas antibodies against other myelin proteins had no effect (Kerlero de Kosbo et al., 1990). Despite the growing conviction that MOG/anti-MOG interactions are mediators of demyelination in rat EAE and MS, a mechanism has not been established. The demyelinating capacity of the MOG/anti-MOG complex may be related to its ability to activate complement (Piddlesden et al., 1993); however, MOG-related demyelination also occurs independently of complement (Dyer and Matthieu, 1994; Menon et al., 1997).

Glycosphingolipids and cholesterol form lateral assemblies ("rafts") in the plasma membrane of cells, into which certain proteins can partition whereas others are excluded (Simons and Ikonen, 1997; Brown and London, 1998; Friedrichson and Kur- 
zchalia, 1998; Varma and Mayor, 1998). Lipid rafts have an important role as platforms for the initiation of signal transduction by favoring specific protein-protein interactions necessary for signal transduction. Ligand or antibody cross-linking of some proteins results in their enhanced partitioning into rafts and their participation in early signal transduction events (Simons and Toomre, 2000). We have proposed that the high content of glycosphingolipids and cholesterol in myelin sheaths may contribute functionally to OL-myelin physiology (Bansal and Pfeiffer, 1989; Pfeiffer et al., 1993; Kim et al., 1995; Bansal et al., 1999). Consistent with this hypothesis, myelin proteins are differentially partitioned into rafts, including the glycosylphosphatidylinositolanchored proteins NCAM (neural cell adhesion molecule)-120 and contactin, doubly acylated proteins Fyn and Lyn kinases, and 2',3'-cyclic nucleotide 3'-phosphodiesterase (CNP) and MOG (Kim et al., 1995; Kramer et al., 1997, 1999; Kim and Pfeiffer, 1999; Simons et al., 2000; Taylor et al., 2002).

In this study we show that antibody-induced cross-linking of MOG in OLs in a complement-independent manner (1) results in the partitioning of MOG into the detergent-insoluble fraction produced by Triton X-100 (TX-100) extraction at $4^{\circ} \mathrm{C},(2)$ concomitantly activates dephosphorylation of $\beta$-tubulin and the $\mathrm{G} \beta$ subunit of the trimeric G-protein complex, as well as the phosphorylation of other yet unidentified proteins, and (3) triggers OL process retraction. We propose that similar events may contribute to a molecular mechanism leading to the initial steps of MOG-related demyelination.

\section{Materials and Methods}

Materials. Antibodies were obtained from the following sources: monoclonal anti-MOG antibody (8-18C5) (Dr. C. Linington, Max-Planck Institute, Germany); anti-proteolipid protein (PLP) antibody (AA3) (Dr. M. Lees, Shriver Center, Waltham, MA); anti-CNP (Bansal and Pfeiffer, 1985); anti-phosphoserine (Calbiochem, San Diego, CA); antiphosphothreonine (Zymed, San Francisco, CA); anti-phosphotyrosine (4G10), polyclonal anti-caveolin antibody, and goat anti-mouse IgG (Transduction Laboratories, San Diego, CA); anti-G $\beta 1-4$ (Santa Cruz Biotechnology, Santa Cruz, CA); horse radish peroxidase-conjugated goat anti-mouse IgG (Chemicon, Temecula, CA); and anti- $\beta$-actin and anti- $\beta$-tubulin antibodies (Sigma, St. Louis, MO). Saponin, methyl- $\beta$ cyclodextrin (MCD), filipin complex, peroxidase-conjugated cholera toxin B subunit, cytochalasin D, nocodazol, okadaic acid, vanadate, 3-[(3cholamidopropyl)dimethylammonio]-1-propanesulfonate (CHAPS), and Hoechst 33342 were obtained from Sigma. The general tyrosine kinase inhibitor PD166285 was a gift from Parke Davis (Ann Arbor, MI). All solutions were prepared with MilliQ $\mathrm{H}_{2} \mathrm{O}$. Protein concentrations were determined by DC protein assay kit (Bio-Rad, Richmond, CA).

Cell culture. Mixed primary cultures and highly enriched populations of maturing OLs were prepared and maintained as described previously (Pfeiffer et al., 1993; Bansal et al., 1996). OL populations were grown in defined medium [modified N2 (mN2)] (Bottenstein and Sato, 1979; Gard and Pfeiffer, 1989) for $7 \mathrm{~d}$ to obtain MOG-expressing OLs.

Immunofluorescence microscopy. Cells were incubated with HEPESbuffered Earle's balanced salt solution (EBSS-HEPES) containing 3\% normal goat serum (NGS) (also used for diluting antibodies) to block nonspecific absorption, and live cells were stained $\left(20 \mathrm{~min}, 4^{\circ} \mathrm{C}\right)$ with $\mathrm{O} 4$ $\mathrm{mAb}$ (1:25), in some cases double-immunolabeled for the surface antigens galactocerebroside (GalC) (O1 mAb, 1:25) (Sommer and Schachner, 1981; Bansal et al., 1989) or MOG (8-18C5 mAb) (1:100). Cells were then incubated with the appropriate secondary antibodies for 20 min: FITC-conjugated goat anti-mouse IgM (1:50; $\mu$-chain specific, for $\mathrm{O} 1$ or $\mathrm{O} 4$; Chemicon) plus $\mathrm{Cy} 3$-conjugated goat anti-mouse IgG (1:500; $\gamma$-chain specific, for MOG; Jackson ImmunoResearch, West Grove, PA). Cells were mounted in $50 \%$ glycerol, $\mathrm{pH} 8.6$, and $2.5 \%$ diazobicyclo- $(2,2,2)$ octane to suppress fading and examined by epifluorescence microscopy. Total cell number was determined by counting cells labeled with a nuclear counterstain ( $1 \mu \mathrm{g} / \mathrm{ml}$ Hoechst dye 33342) included with the secondary antibodies. Washing between steps was performed with three 5 min changes of $1 \%$ NGS and EBSS-HEPES. Data of cell counting from at least 10 fields were used for each preparation. To assess the integrity of microtubules and microfilaments after nocodazol $(10 \mu \mathrm{M} ; 0,30,60,90$, and $120 \mathrm{~min})$ or cytochalasin $\mathrm{D}(20 \mu \mathrm{M} ; 0,30,60,90$, and $120 \mathrm{~min}$ ) treatments, insoluble tubulin and actin, respectively, were stained as described by Pigino et al. (2001). Briefly, cells were fixed with $4 \%$ paraformaldehyde $\left(15 \mathrm{~min}, 4^{\circ} \mathrm{C}\right)$, washed with $0.13 \mathrm{M}$ HEPES, $\mathrm{pH} 6.9$, $2 \mathrm{mM} \mathrm{MgCl}, 10 \mathrm{~mm}$ EGTA, and extracted in the same buffer plus $0.2 \%$ TX-100 for $5 \mathrm{~min}$ at $37^{\circ} \mathrm{C}$ before tubulin staining, or with $0.02 \%$ saponin for $2 \mathrm{~min}$ at $37^{\circ} \mathrm{C}$ before actin staining.

Estimation of OL morphology after MOG cross-linking. OLs grown in $\mathrm{mN} 2$ medium were washed with $1 \%$ bovine serum albumin (BSA) in DMEM and incubated at $37^{\circ} \mathrm{C}$ with monoclonal anti-MOG antibody [8-18C5; 1:100 (156 $\mu \mathrm{g} / \mathrm{ml}$ IgG diluted in freshly prepared mN2; antibody concentration was determined by QuantiType Radial Immunodiffusion kit, QED Bioscience, San Diego, CA)] for various time intervals (5-15 min). Antibody was washed out by two changes of DMEM. Goat anti-mouse IgG (1:500, diluted in DMEM) was added for 5-15 min at $37^{\circ} \mathrm{C}$. In some experiments, plates were incubated with $0.1 \mu \mathrm{M}$ PD 166285 $\left(3 \mathrm{hr}, 37^{\circ} \mathrm{C}\right)$ or $10 \mathrm{~nm}$ okadaic acid $\left(3 \mathrm{hr}, 37^{\circ} \mathrm{C}\right)$ before MOG crosslinking. In some other experiments, the antibody-containing media was removed, and the cells were grown further in fresh medium for 2, 4, or 14 $\mathrm{hr}$. Controls were subjected to the same schedule of washes and incubations. Plates were put on an ice tray, and antibody was washed out by two changes of EBSS-HEPES. Live cells were stained $\left(20 \mathrm{~min}, 4^{\circ} \mathrm{C}\right)$ with $\mathrm{O} 4$ $\mathrm{mAb}(1: 25)$ as described before and analyzed by epifluorescence microscopy. The areas occupied by mature OLs in randomly selected fields were compared, using Adobe Photoshop 5.0 (number of pixels per cell). Averages and SEM were calculated $(n=20-35)$, and evaluation of statistics significance between conditions was made using Student's two-tail $t$ test.

Antibody perturbation and preparation of cell lysate. OLs grown in $\mathrm{mN} 2$ medium were washed with $1 \%$ BSA in DMEM and incubated at $37^{\circ} \mathrm{C}$ with monoclonal anti-MOG antibody [8-18C5; 1:25-1:500 (624-31 $\mu \mathrm{g} / \mathrm{ml} \mathrm{IgG}$, diluted in fresh $\mathrm{mN} 2)]$ for various time intervals (1-60 min). Antibody was washed out by two changes of DMEM. Goat anti-mouse $\operatorname{IgG}\left(1: 25-1: 10,000\right.$, diluted in DMEM) was added for $1-30 \mathrm{~min}$ at $37^{\circ} \mathrm{C}$ to cross-link MOG/anti-MOG complexes. Controls, including no additions or treatment with only primary or secondary antibody, were subjected to the same schedule of washes and incubations. Some plates were treated with monoclonal antibody $\mathrm{O} 10$ (recognizing an extracellular epitope of PLP, diluted 1:10) (Jung et al., 1996) and secondary antibody in the same way as anti-MOG treatment. In some experiments, plates were incubated with $5 \mathrm{~mm} \mathrm{MCD}\left(15 \mathrm{~min}, 37^{\circ} \mathrm{C}\right.$; see below), $10 \mu \mathrm{M}$ nocodazol $\left(2 \mathrm{hr}, 37^{\circ} \mathrm{C}\right), 20 \mu \mathrm{m}$ cytochalasin $\mathrm{D}\left(2 \mathrm{hr}, 37^{\circ} \mathrm{C}\right), 10 \mathrm{~nm}$ okadaic acid $\left(3 \mathrm{hr}, 37^{\circ} \mathrm{C}\right)$, or $0.1 \mu \mathrm{M}$ PD166285 $\left(3 \mathrm{hr}, 37^{\circ} \mathrm{C}\right)$ before MOG crosslinking. In some cases, the control and antibody-containing media were removed, and the cells were grown further in fresh medium for 15 or 30 min. After cross-linking, plates were put on an ice-tray and washed twice with ice-cold PBS or with $\mathrm{mN} 2$ and then incubated at $37^{\circ} \mathrm{C}$ for 15 or 30 min. Cells were scraped into $0.5 \mathrm{ml}$ of $150 \mathrm{~mm} \mathrm{NaCl}, 5 \mathrm{~mm}$ EDTA, $25 \mathrm{~mm}$ Tris-Cl buffer, $\mathrm{pH} 7.5$, containing $1 \mathrm{~mm}$ PMSF, $10 \mu \mathrm{g} / \mathrm{ml}$ leupeptinaprotinin, $50 \mathrm{~mm} \mathrm{NaF}, 10 \mathrm{~mm} \mathrm{NaP}_{2} \mathrm{O}_{7}$, and $1 \mathrm{~mm} \mathrm{Na} o$-vanadate (scraping buffer) and passed 10 times (on ice) through a 30 ga needle.

Detergent extraction and sucrose gradient ultracentrifugation. Triton X-100 (1\% final concentration) was added to cell lysates and incubated for $30 \mathrm{~min}$ at either 4 or $37^{\circ} \mathrm{C}$ (Kim and Pfeiffer, 1999; Taylor et al., 2002) (see Results). The TX-100 extracts were centrifuged $\left(13,000 \times g, 4^{\circ} \mathrm{C}, 10\right.$ $\mathrm{min})$ to separate them into detergent-insoluble pellet and detergentsoluble supernatant fractions.

The supernatant fraction was precipitated with $2 \mathrm{vol}$ of ethanol at $-20^{\circ} \mathrm{C}$ overnight and centrifuged $\left(13,000 \times g, 4^{\circ} \mathrm{C}, 10 \mathrm{~min}\right)$, and the new supernatant was discarded. Finally, both the original detergent-insoluble pellet and the ethanol-precipitated soluble fraction pellets were solubilized in equal volumes (to allow comparison of the relative amount of each protein in the two fractions) of sample buffer for analysis by SDS-PAGE.

For sucrose gradient ultracentrifugation, TX-100-insoluble pellet frac- 
tions were resuspended in $0.5 \mathrm{ml}$ of scraping buffer plus $1 \%$ TX-100, mixed with $2 \mathrm{M}$ sucrose $(1 \mathrm{ml})$, overlaid with $1 \mathrm{M}(2 \mathrm{ml})$ and $0.2 \mathrm{M}(1.5 \mathrm{ml})$ sucrose, and centrifuged for $16 \mathrm{hr}$ at 45,000 rpm (SW $55 \mathrm{Ti}, \sim 200,000 \times$ $\mathrm{g}$; Beckman) at $4^{\circ} \mathrm{C}$. After centrifugation, $0.5 \mathrm{ml}$ fractions were collected at $4^{\circ} \mathrm{C}$ from the top to the bottom of the gradient.

Cholesterol extraction. To disrupt cholesterol in OL membranes before TX-100 extraction, cell lysates were treated with saponin (final $0.2 \%$ ) on ice for $30 \mathrm{~min}$ and centrifuged $(13,000 \times \mathrm{g}, 10 \mathrm{~min}$ ) (Kim and Pfeiffer, 1999). The supernatant (S1) was collected. The pellet was extracted with $0.5 \mathrm{ml}$ of $1 \%$ TX-100 in scraping buffer for $30 \mathrm{~min}$ (see above) and centrifuged $(13,000 \times g, 10 \mathrm{~min})$, and the TX-100-soluble fraction (S2) and pellet were separated. Supernatants $\mathrm{S} 1$ and $\mathrm{S} 2$ were precipitated with ethanol at $-20^{\circ} \mathrm{C}$ overnight and centrifuged $(13,000 \times g, 10 \mathrm{~min})$. Pellets and ethanol-precipitated supernatant fractions were resuspended in equal volumes (to allow a comparison of the relative amount of each protein in the two fractions) of sample buffer for analysis by SDS-PAGE. To remove cholesterol from live cells, OLs in culture were treated with 5 mM MCD for $15 \mathrm{~min}$ at $37^{\circ} \mathrm{C}$ (Ledesma et al., 1998), before MOG crosslinking. Cholesterol levels were evaluated by filipin staining $(50 \mu \mathrm{g} / \mathrm{ml}$, $\left.30 \mathrm{~min}, 4^{\circ} \mathrm{C}\right)$.

SDS-PAGE and Western blotting analysis. Equal volumes of the soluble and insoluble fractions (see above) of the various TX-100 extracts were solubilized in sample buffer [ $50 \mathrm{~mm}$ Tris- $\mathrm{HCl}$, pH 6.8, 2.5\% glycerol, 5\% SDS, $4 \mathrm{~m}$ urea, $0.01 \%$ bromophenol blue, with or without $10 \mathrm{~mm}$ DTT (see Results)], loaded onto acrylamide gels (Protean II mini-cell apparatus, Bio-Rad), and run at constant voltage (120 V, 1-2 hr). The proteins were transferred to polyvinylidene difluoride (PVDF) membranes (Hybond-P, Amersham Biosciences, Piscataway, NJ) at $4^{\circ} \mathrm{C}$ with a constant voltage ( $100 \mathrm{~V}, 1 \mathrm{hr})$. The blots were blocked with 5\% nonfat milk or $5 \%$ BSA (Sigma) depending on the antibody ( $1 \mathrm{hr}$, room temperature) before immunostaining and detection [enhanced chemiluminescence (ECL Plus), Amersham Biosciences].

Two-dimensional PAGE. Mature OL cells were scraped into $25 \mathrm{~mm}$ Tris-Cl buffer, $\mathrm{pH}$ 7.5, containing 2\% CHAPS, $1 \mathrm{~mm}$ PMSF, $10 \mu \mathrm{g} / \mathrm{ml}$ leupeptin-aprotinin, $50 \mathrm{~mm} \mathrm{NaF}, 10 \mathrm{~mm} \mathrm{NaP} \mathrm{O}_{7}$, and $1 \mathrm{~mm} \mathrm{Na}$ $o$-vanadate. Proteins were precipitated overnight with $2 \mathrm{vol}$ of ethanol at $-20^{\circ} \mathrm{C}$. Cell extracts $(300 \mu \mathrm{g}$ of protein) were solubilized in rehydration buffer: $7 \mathrm{M}$ urea, $2 \mathrm{M}$ thiourea, 2\% CHAPS, $0.5 \%$ immobilized $\mathrm{pH}$ gradient (IPG) buffer 4-7 (Amersham Biosciences), 100 mм DTT, 0.001\% bromophenol blue. All samples were left in rehydration buffer for $1 \mathrm{hr}$ at room temperature with occasional mixing before centrifugation $(10,000 \times g, 10 \mathrm{~min})$ to clear particulate matter. Sample supernatant was added to IPGphor coffins (Amersham Biosciences), and an Immobiline Dry Strip, pH 4-7, isoelectric focusing gel (Amersham Biosciences) was placed over the solution. The IPG strips were allowed to rehydrate overnight. Proteins were separated in the first dimension $(200 \mathrm{~V}, 1 \mathrm{hr} ; 500 \mathrm{~V}$, $1 \mathrm{hr} ; 1000 \mathrm{~V}, 1 \mathrm{hr}$; ramped to $8000 \mathrm{~V}, 30 \mathrm{~min}$; held at $8000 \mathrm{~V}$ for 30,000 $\mathrm{Vh}$ ) at $20^{\circ} \mathrm{C}$ using an IPGphor electrophoresis unit (Amersham Biosciences). After isoelectric focusing, the gel was equilibrated first for 15 min with $130 \mathrm{~mm}$ DTT in an equilibration buffer containing $6 \mathrm{~m}$ urea, 50 mм Tris, pH 6.8, 30\% glycerol, 2\% SDS, and second for 15 min with 135 mM iodoacetamide in the same equilibration buffer. SDS-PAGE was performed in 10\% acrylamide running gels at a constant current $(15 \mathrm{~mA}, 14$ hr), using a Hoefer DALT vertical system (Amersham Biosciences). The proteins were transferred to PVDF membranes (Hybond-P, Amersham Biosciences) at constant current ( $400 \mathrm{~mA}, 14 \mathrm{hr}$ ). In some cases, gels were stained with ammoniacal silver nitrate or Colloidal Blue (Invitrogen, Carlsbad, CA).

\section{Results}

Antibody-induced cross-linking of MOG on the surface of differentiated OLs in culture induces its partitioning into a detergent insoluble fraction

Glycosphingolipid-cholesterol microdomains are often studied biochemically by taking advantage of their insolubility in nonionic detergents. We have shown previously that in myelin membrane $\sim 40 \%$ of MOG is present in TX-100 $\left(4^{\circ} \mathrm{C}\right)$ insoluble, low-density, glycosphingolipid-cholesterol-rich

\begin{tabular}{|c|c|c|c|c|c|c|}
\hline $\begin{array}{l}\text { Days in } \\
\text { Culture }\end{array}$ & 3 & 4 & 5 & 6 & 7 & 8 \\
\hline \multirow[t]{2}{*}{ MOG } & . & $=$ & - & - & & \\
\hline & P S & P $\quad S$ & P S & $P \quad S$ & $P \quad S$ & $\begin{array}{ll}\mathrm{P} & \mathrm{S}\end{array}$ \\
\hline $\begin{array}{c}\text { \%MOG+/O1+ } \\
\text { Cells }\end{array}$ & 33 & 62 & 77 & 85 & 89 & 93 \\
\hline $\begin{array}{c}\% 01+/ \text { Total } \\
\text { Cells }\end{array}$ & 37 & 69 & 66 & 72 & 78 & 78 \\
\hline
\end{tabular}

Figure 1. Developmental association of MOG with detergent-insoluble microdomains in $0 \mathrm{Ls}$. Western blot analysis of MOG in pellet $(\mathrm{P}$, insoluble) and supernatant $(\mathrm{S}$, soluble) fractions during TX-100 extraction at $4^{\circ} \mathrm{C}$ from $0 \mathrm{Ls}$ ( $3-8 \mathrm{~d}$ in culture). Cell lysate ( $20 \mu \mathrm{g}$ of protein) was extracted, and the entire yield in each fraction was loaded in the gels for each condition. The percentage of $01+/$ total cells and MOG + $/ 01+$ cells in each preparation is indicated (estimated by immunofluorescence microscopy as described in Materials and Methods). This figure represents a typical result of three independent experiments.

microdomains (lipid rafts) (Kim and Pfeiffer, 1999; Taylor et al., 2002). In contrast, when cultures enriched for OLs were extracted with TX-100 at $4^{\circ} \mathrm{C}$, nearly all of MOG was detected in the soluble fraction at all ages studied (Fig. 1). We conclude that the association of MOG in the relatively immature, myelin-like membranes of OLs in culture (Singh and Pfeiffer, 1985) differs in this important characteristic from that in mature myelin in association with axons.

Noting that cross-linking of a number of membrane receptors with antibodies leads to their repartitioning into lipid rafts (Simons and Toomre, 2000), we treated MOG-positive OLs at $37^{\circ} \mathrm{C}$ with anti-MOG antibody (1:100) for 15 min before detergent extraction; again, nearly all of the MOG was found in the soluble fraction (Fig. 2A). However, when OLs were first treated with anti-MOG (primary antibody) and then were further treated with a cross-linking secondary antibody (1:100; anti-IgG) for an additional $15 \mathrm{~min}$ at $37^{\circ} \mathrm{C}$, MOG was recovered nearly entirely in the detergent-insoluble fraction (Fig. 2 A). Several control studies

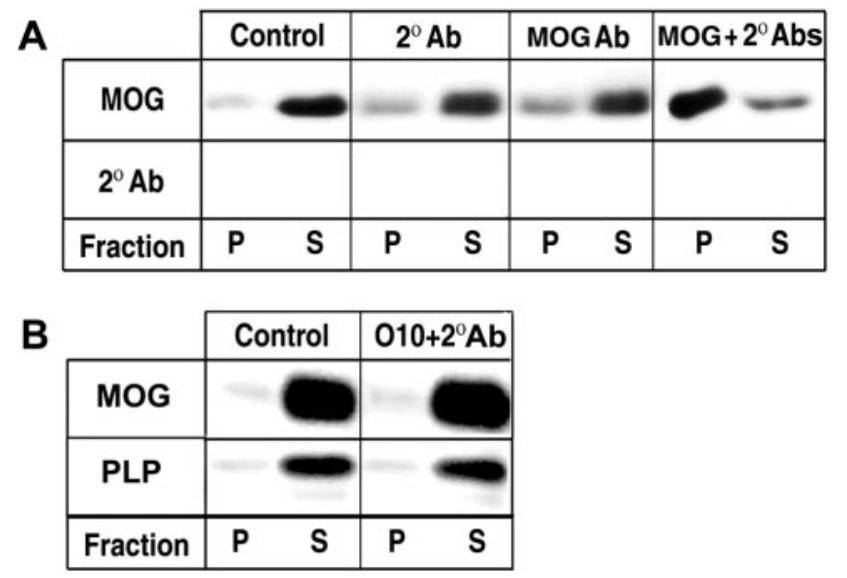

Figure 2. MOG repartitioning after antibody-induced cross-linking. $A, B$, Western blot analyses of $M O G(A, B)$, anti-lgG (to control for residual antibody light-chain reaction in the $\sim 25 \mathrm{kDa}$ region of blots; $\left.2^{\circ} \mathrm{Ab}\right)(A)$ and $\mathrm{PLP}(B)$ in pellet (P, insoluble) and supernatant $(\mathrm{S}$, soluble) fractions during TX-100 extraction at $4^{\circ} \mathrm{C}$ of mature OLs. Cells were incubated for 15 min with anti-MOG mAb 8-18C5 (1:100, MOG Ab), anti-mouse lgG (1:100, $\left.2^{\circ} \mathrm{Ab}\right)$, subsequently with MOG Ab and $2^{\circ} \mathrm{Ab}(A)$, subsequently with 010 (1:10) and anti-mouse $\operatorname{lgM}(1: 100)(B)$ or media alone (control, no Ab). After scraping, cell lysates ( $20 \mu \mathrm{g}$ of protein) were extracted with TX-100 at $4^{\circ} \mathrm{C}$ and separated into pellets and supernatants by centrifugation, and the entire yield in each fraction was loaded in the gels for each condition. The figure represents a typical result of three independent experiments. 
were performed (Fig. 2): (1) secondary antibody alone had no effect on MOG partitioning; (2) immunoblot analysis confirmed that the signal observed was not attributable to the detection of $25 \mathrm{kDa}$ anti-MOG antibody light chains (which, were they present, could potentially be confused with $28 \mathrm{kDa}$ MOG/anti-MOG signals in reducing gel Western blots); (3) the detergent solubilities of two other major myelin proteins, CNP and PLP (both mostly soluble during extraction of OLs in culture with TX-100 at $\left.4^{\circ} \mathrm{C}\right)$, were unaltered by the anti-MOG/anti-IgG cross-linking (data not shown); (4) similar cross-linking of PLP with a monoclonal antibody against an extracellular domain (010, Jung et al., 1996) did not alter the detergent solubility of either PLP or MOG (Fig. $2 B$ ).

We conclude that cross-linking MOG on the surface of differentiated OLs in culture results in a major change in its detergent solubility properties. We therefore initiated a series of experiments to assess the time course, dose-response, biochemical characteristics, and potential functional significance of the MOG cross-linking-mediated detergent insolubility of MOG.

\section{MOG partitioning occurs during treatment with low doses and short durations of anti-MOG}

The detergent insolubility of MOG in response to antibody crosslinking was studied as a function of dose and duration of treatment of both the primary and secondary antibodies.

At a constant dilution of secondary antibody (1:100), the partitioning of MOG into the detergent-insoluble fraction was essentially complete at dilutions of primary antibody ranging from $1: 25(624 \mu \mathrm{g} / \mathrm{ml} \mathrm{IgG})$ to $1: 500(31 \mu \mathrm{g} / \mathrm{ml} \mathrm{IgG})$ (Fig. 3A). Treatment of OLs with anti-MOG (1:100) followed by 15 min of crosslinking with secondary antibody $(1: 100,23 \mu \mathrm{g} / \mathrm{ml})$ as a function of time (Fig. $3 B$ ) resulted in the partitioning into the insoluble fraction of $\sim 80 \%$ of MOG within $1 \mathrm{~min}$ and nearly all MOG within $5 \mathrm{~min}$ [with longer exposures (e.g., $1 \mathrm{hr}$ ), a minor amount of MOG reappeared in the soluble fraction in some experiments].

With primary antibody at a constant dilution (1:100) and duration of treatment (15 min), >90\% of MOG partitioned into the detergent-insoluble fraction during cross-linking with secondary antibody dilutions up to 1:500 (data not shown). Under these conditions, significant partitioning was observed within $1 \mathrm{~min}$ and was nearly complete within 5 min (Fig. 3C).

On the basis of these results, the following conditions were chosen for subsequent analyses: anti-MOG, 1:100 for $5 \mathrm{~min}$; cross-linking secondary antibody, 1:500 for $5 \mathrm{~min}$. Nevertheless, at these antibody concentrations (anti-MOG 1:100; secondary antibody 1:500) even 1 min incubations with each antibody resulted in $\sim 50 \%$ partitioning of MOG (Fig. 3D, e). We conclude that the cross-linking-induced partitioning of MOG into a detergent-insoluble fraction occurs rapidly and at low concentrations of antibody.

\section{Detergent-insoluble MOG from differentiated OLs in culture has both low- and high-density components}

Insolubility of a protein in TX-100 at $4^{\circ} \mathrm{C}$ by itself is not sufficient to conclude that these proteins are associated with lipid rafts; insolubility can also be derived from protein-protein interactions with, for example, cytoskeletal elements (Pfeiffer et al., 1993; De Angelis and Braun, 1996; Kim and Pfeiffer, 1999; Taylor et al., 2002). We therefore applied three additional, well established biochemical criteria. During TX-100 extraction at $4^{\circ} \mathrm{C}$, raft-associated proteins float to a characteristic, low-bouyant density in density (e.g., sucrose) gradients (Brown and Rose, 1992; Simons and Ikonen, 1997); raft-associated proteins insoluble in TX-100 at $4^{\circ} \mathrm{C}$ generally become solubilized when the ex-
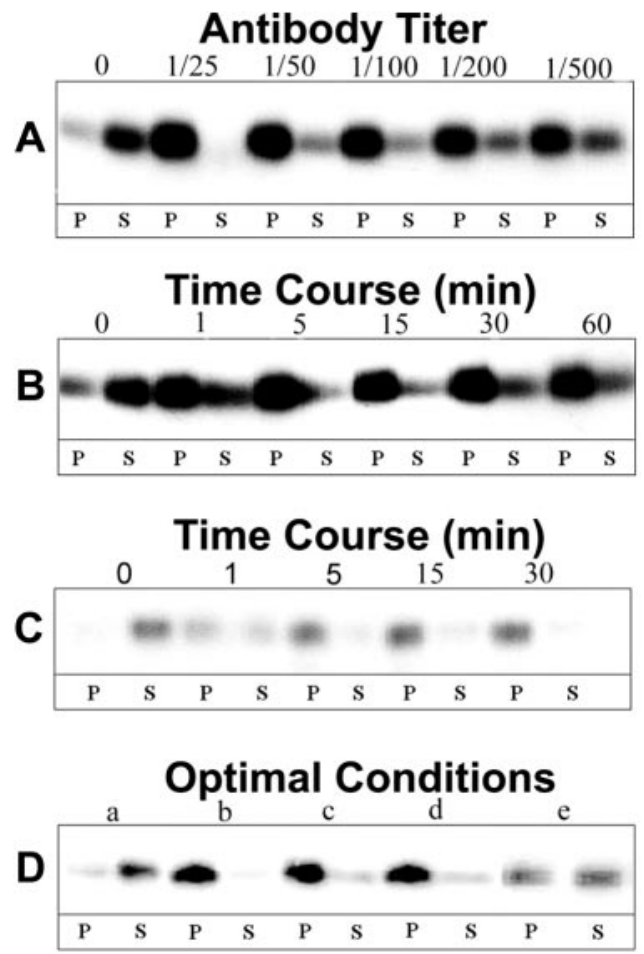

Figure 3. MOG repartitioning as a function of antibody dose and incubation time. Western blot analysis of MOG in the insoluble pellet $(\mathrm{P})$ and soluble $(\mathrm{S})$ fractions during $\mathrm{TX}-100$ extraction at $4^{\circ} \mathrm{C}$ of mature $0 \mathrm{Ls}$ after various treatments. $A, 1^{\circ} \mathrm{Ab}$ dose-response: cells were incubated for $15 \mathrm{~min}$ with varying concentrations of anti-MOG mAb 8-18C5 (1:25-1:500), and then for 15 min with anti-mouse $\lg \mathrm{G}(1: 100) ; B, 1^{\circ} \mathrm{Ab}$ time course: cells were incubated for $1-60$ min with anti-MOG mAb 8-18C5 (1:100), and then for 15 min with anti-mouse $\operatorname{lgG}(1: 100) ; C, 2^{\circ}$ Ab time course: cells were incubated for $15 \mathrm{~min}$ with anti-MOG mAb 8-18C5 (1:100), and then for 1-30 min with anti-mouse $\lg G(1: 100) ; D, 0 \mathrm{Ls}$ incubated under the following conditions for $1^{\circ}$ and $2^{\circ}$ Ab doses and incubation times: control, no $\mathrm{Ab}(a) ; 1^{\circ} \mathrm{Ab} 1: 10015 \mathrm{~min}, 2^{\circ} \mathrm{Ab} 1: 10015 \mathrm{~min}(b)$; $1^{\circ} \mathrm{Ab} \mathrm{1:100} 5 \mathrm{~min}, 2^{\circ} \mathrm{Ab} 1: 1005 \mathrm{~min}(\mathrm{c}) ; 1^{\circ} \mathrm{Ab} 1: 1005 \mathrm{~min}, 2^{\circ} \mathrm{Ab} \mathrm{1:500} 5 \mathrm{~min} ;($ d $) 1^{\circ} \mathrm{Ab}$ 1:100 1 $\min , 2^{\circ} \mathrm{Ab} 1: 5001 \mathrm{~min}(e)$. Controls were similarly incubated with media alone. After scraping, cell lysates (20 $\mu \mathrm{g}$ of protein) were extracted with TX-100 at $4^{\circ} \mathrm{C}$ and separated into pellets and supernatants by centrifugation, and the entire yield in each fraction was loaded in the gels for each condition. The figure represents a typical result of three independent experiments.

traction is performed either at $37^{\circ} \mathrm{C}$ (Brown and Rose, 1992) or at $4^{\circ} \mathrm{C}$ after previous treatment with the cholesterol-binding agent saponin (Rothberg et al., 1990; Cerneus et al., 1993; Hanada et al., 1995; Stulnig et al., 1997; Ledesma et al., 1998). These three criteria are fulfilled by MOG present in the detergent-insoluble fraction obtained during treatment of purified myelin with TX-100 at $4^{\circ} \mathrm{C}$ (Kim and Pfeiffer, 1999; Taylor et al., 2002) (Fig. 4A).

In contrast to myelin, the detergent-insoluble MOG from antibody cross-linked OLs (Fig. 2A) was distributed in both light and heavy fractions during floating on sucrose gradients, both of which were poorly solubilized by extraction with TX-100 at $37^{\circ} \mathrm{C}$ (Fig. $4 B$ ). On the other hand, pretreatment of the cell lysate with saponin, or depletion of cholesterol by previous treatment of the OLs with methyl $\beta$-cyclodextrin (see Fig. $6 A, B$ ), did result in efficient solubilization of the light fractions (but much less efficiently for the heavy fractions) during extraction with TX-100 at $4^{\circ} \mathrm{C}$ (Fig. $4 \mathrm{~B}$ ). The small amount of detergent-insoluble material obtained from untreated control cells had similar characteristics as that from cross-linked cells (data not shown). The light fraction was further analyzed for the presence of GM1 ganglioside (a widely used marker for lipid rafts) and caveolin (a marker of caveolae, a subgroup of lipid rafts) (Abrami et al., 2001) (Fig. $4 C, D)$. Both of these markers were enriched in the light fractions 


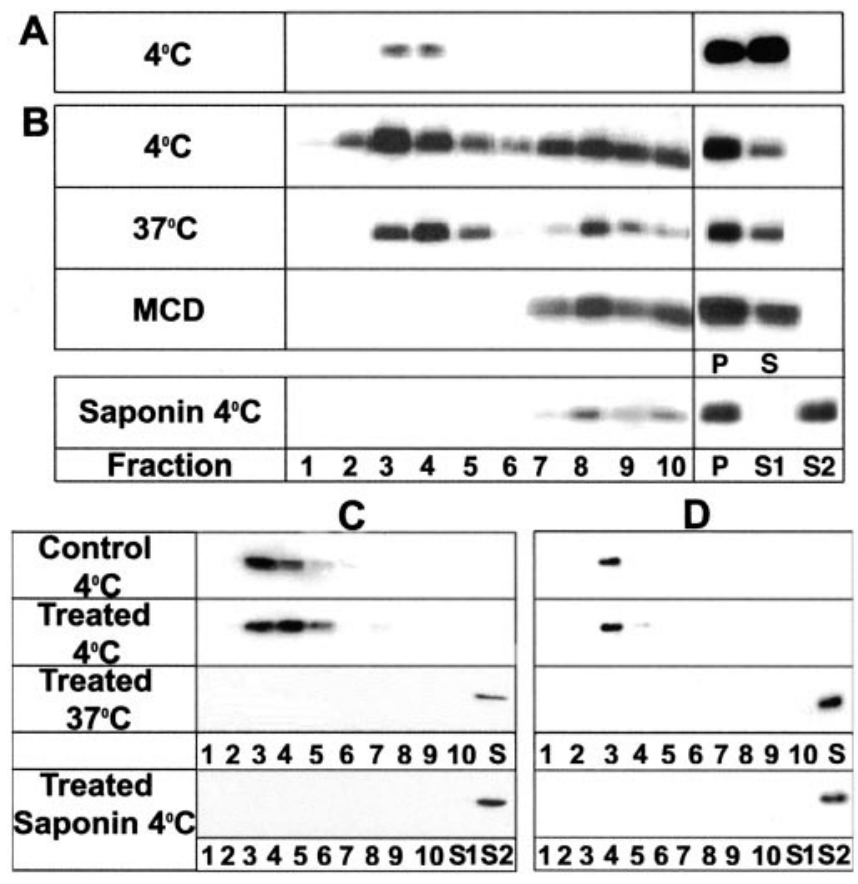

Figure 4. Further analyses of the TX-100-insoluble fractions. Western blot analyses of MOG were performed on either purified myelin (extraction at $4^{\circ} \mathrm{C}$ ) $(A)$ or treated OLS $(B)$ [anti-MOG mouse $\mathrm{mAb} 18-18 C 5(1: 100,5 \mathrm{~min})$ followed by anti-mouse lgG (1:500, $5 \mathrm{~min})]$. OLs were extracted with TX-100 at $4^{\circ} \mathrm{C}, 37^{\circ} \mathrm{C}$, and $4^{\circ} \mathrm{C}$ after pretreatment of the cell lysate with saponin (Saponin $4^{\circ} \mathrm{C}$ ) or $\mathrm{MCD} 4^{\circ} \mathrm{C}$ after pretreatment of the cells in culture with $5 \mathrm{~mm}$ methyl $\beta$-cyclodextrin for $15 \mathrm{~min}$ at $37^{\circ} \mathrm{C}$. The insoluble fractions (myelin, $50 \mu \mathrm{g} ; 0 \mathrm{Ls}, 300 \mu \mathrm{g}$ of protein) were then further fractionated by centrifugation on sucrose gradients as described in Materials and Methods (fraction 1, top of gradient; i.e., lowest density). C, D, Western blot analysis of $\mathrm{GM} 1$ detected by reaction with cholera toxin $B$ subunit $(C)$ or caveolin after various treatments $(D)$ as described above in $B .0 \mathrm{Ls}$ were untreated $\left(\mathrm{Control} 4^{\circ} \mathrm{C}\right)$ or first antibodytreated (above) and extracted with TX-100 at $4^{\circ} \mathrm{C}\left(\right.$ Treated $4^{\circ} \mathrm{C}$ ) or $37^{\circ} \mathrm{C}\left(\right.$ Treated $\left.37^{\circ} \mathrm{C}\right)$ or at $4^{\circ} \mathrm{C}$ after pretreatment with saponin (Treated Saponin $4^{\circ} \mathrm{C}$ ). $P$ and $\mathrm{S}$ are the insoluble and soluble fractions, respectively, after extraction with TX-100 at the indicated temperatures. S1, Soluble fraction after pretreatment of the cell lysate with saponin; $\$ 2$, soluble fraction after pretreatment with saponin followed by extraction with TX-100 at $4^{\circ} \mathrm{C}$. Cell lysate $(5 \mu \mathrm{g}$ of protein in $A$; $20 \mu \mathrm{g}$ of protein in $B$ ) was extracted, and the entire yield in each fraction was loaded in the gels for each condition ( $A, B$, right panel). Typical results of four independent experiments are shown.

during TX-100 extraction at $4^{\circ} \mathrm{C}$, were completely solubilized during extraction at $37^{\circ} \mathrm{C}$ or pretreatment with saponin, and were similarly distributed in control and MOG cross-linked cells. We conclude that during antibody cross-linking, MOG becomes repartitioned into a preexisting TX-100-insoluble $\left(4^{\circ} \mathrm{C}\right)$ fraction with key characteristics of lipid rafts (low density, solubilization by saponin pretreatment, GM1, caveolin) and a higher density fraction that is likely to be based on protein-protein interactions.

\section{Role of the cytoskeleton in MOG cross-linking}

Dyer and Matthieu (1994) reported that MOG becomes associated with microtubules after long exposures of OLs to high doses of anti-MOG antibodies. Because cytoskeletal elements can be insoluble in TX-100 at $4^{\circ} \mathrm{C}$ (Pereyra et al., 1988), the distributions on sucrose gradients of tubulin and actin in the TX-100-insoluble material $\left(4^{\circ} \mathrm{C}\right)$ were analyzed (Fig. $\left.5 \mathrm{~A}\right)$. As for MOG, both proteins were present in both the light and heavy fractions. However, in contrast to MOG, both tubulin and actin in the light fractions were solubilized during TX-100 extraction at $37^{\circ} \mathrm{C}$, as well as at $4^{\circ} \mathrm{C}$ after saponin pretreatment (Fig. $5 A$ ). When OLs were first treated with either nocodazol or cytochalasin $\mathrm{D}$ to depolymerize

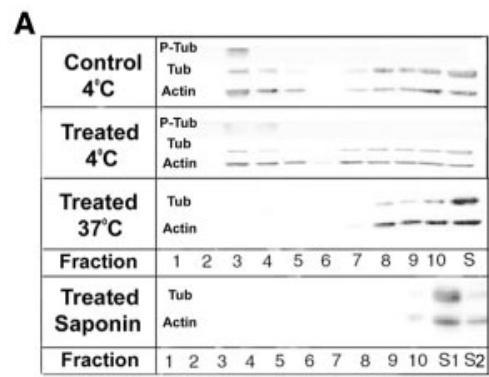

B

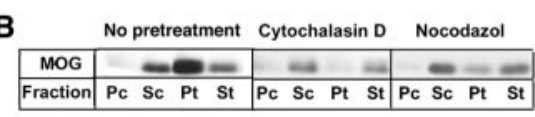

C

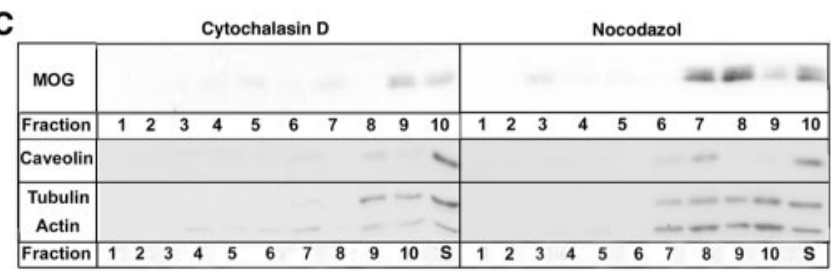

Figure 5. Role of cytoskeletal proteins in lipid raft formation and MOG repartitioning. Control and antibody-treated [anti-MOG mAb 8-15C5 (1:100, 5 min), anti-mouse lgG (1:500, 5 $\mathrm{min})] \mathrm{OLs}$ in culture were detergent extracted. The soluble $(S)$ and insoluble pellet $(\mathrm{P})$ fractions during TX-100 extraction $\left(4^{\circ} \mathrm{C}\right.$ or $37^{\circ} \mathrm{C}$, or pretreatment with saponin followed by TX-100 extraction at $4^{\circ} \mathrm{C}$ ) were analyzed by Western blot. A typical result from three independent experiments is shown. $A$, Analysis of phospho- $\beta$-tubulin (P-Tub), $\beta$-tubulin (Tub), and actin (Actin). Insoluble fractions (300 $\mu \mathrm{g}$ of protein) were loaded on sucrose gradients, and fractions were collected from the top (1) to the bottom (10) of the gradient. S, Soluble fraction after TX-100 extraction at 4 or $37^{\circ} \mathrm{C} ; \mathrm{S1}$, soluble fraction after pretreatment with saponin; $\$ 2$, soluble fraction after pretreatment with saponin followed by extraction with TX-100 at $4^{\circ} \mathrm{C}$. Note that essentially all of the tubulin becomes dephosphorylated during cross-linking of MOG; tubulin and actin that are present in the low-density fractions $(3-5)$ when cells are extracted at $4^{\circ} \mathrm{C}$ become soluble when extractions are performed at 37 or $4^{\circ} \mathrm{C}$ after pretreatment with saponin. $B$, Western blot analysis of MOG after a $2 \mathrm{hr}$ pretreatment with either $20 \mu \mathrm{m}$ cytochalasin D or $10 \mu \mathrm{M}$ nocodazol. Soluble and insoluble fractions from control and antibody-treated cells after extraction with TX-100 at $4^{\circ} \mathrm{C}$ are Sc, Pc, St, and Pt, respectively. Cell lysate (20 $\mu \mathrm{g}$ of protein) was extracted, and the entire yield in each fraction was loaded in the gels for each condition. Note that the repartitioning of $M O G$ into lipid rafts during cross-linking is virtually eliminated during dissociation of the actin (cytochalasin D) or tubulin (nocodazol) cytoskeleton. C, The TX-100 $\left(4^{\circ} \mathrm{C}\right)$-insoluble fractions from drug- and antibody-treated cells $(B, \mathrm{Pt})$ were analyzed on sucrose gradients (300 $\mu \mathrm{g}$ of protein). Note that not only MOG but also caveolin, tubulin, and actin are absent from the low-density DIG fractions (3-5) during pretreatment of the cells with cytoskeleton-disrupting agents.

microtubules or microfilaments, respectively (Fig. $6 C-F$ ), the redistribution of MOG into the insoluble fraction (TX-100, $4^{\circ} \mathrm{C}$ ) was nearly entirely eliminated, and the small amount of remaining insoluble material was present in the heavy fractions (Fig. $5 B, C)$. However, further analysis on sucrose gradients showed that under these conditions caveolin, tubulin, and actin were also present in the heavy fractions (Fig. 5C), suggesting that cytoskeletal disruption affected raft integrity in general rather than the redistribution of MOG in particular.

\section{Specific proteins are phosphorylated in response to MOG antibody cross-linking}

In a number of systems, ligand- or antibody-mediated partitioning of proteins into lipid rafts results in the initiation of signal transduction cascades (Simons and Toomre, 2000). Because phosphorylation of proteins is an integral part of signal transduction mechanisms, we examined by Western blotting the 

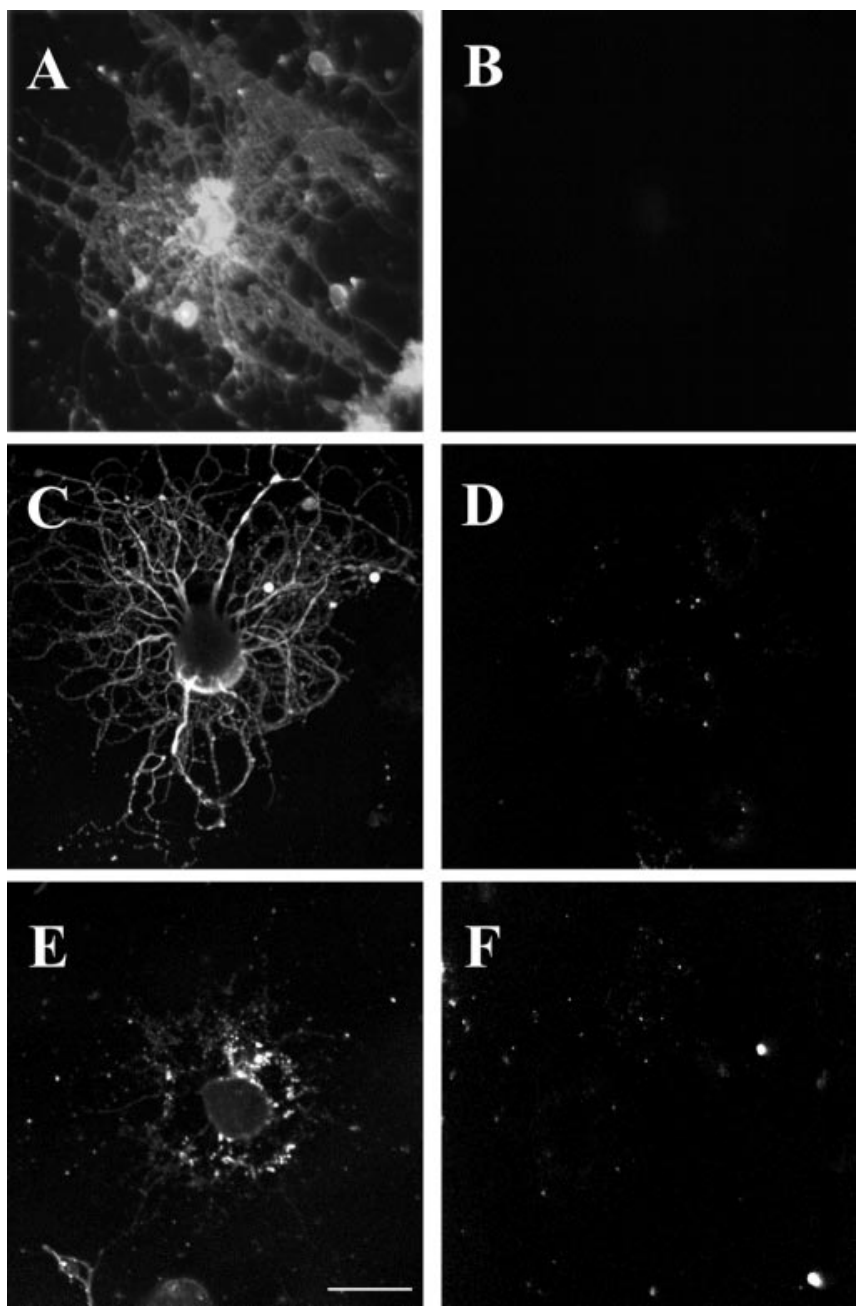

Figure 6. Removal of cholesterol, or depolymerization of microfilaments or microtubules, in OLs in culture. Treatment with MCD, nocodazol, or cytochalasin D resulted in the removal of nearly all of the cholesterol $(A, B)$ or depolymerization of microtubules $(C, D)$ or actin microfilaments $(E, F)$, respectively. $A, B$, Mature $0 \mathrm{Ls}$ in culture were either not treated $(A)$ or treated with $5 \mathrm{~mm}$ MCD for $15 \mathrm{~min}(B)$ before staining with filipin to assess the efficiency of removal of cholesterol by the drug. $C, D$, Mature $0 \mathrm{Ls}$ in culture were either not treated $(C$ or treated with 10 $\mu \mathrm{m}$ nocodazol for $2 \mathrm{hr}(D)$ to assess the efficiency of depolymerization of microtubules by the drug, as analyzed by immunostaining with anti-tubulin antibodies. $E, F$, Mature $0 \mathrm{Ls}$ in culture were either not treated $(E)$ or treated with $20 \mu \mathrm{m}$ cytochalasin $D$ for $2 \mathrm{hr}(F)$ to assess the efficiency of depolymerization of actin microfilaments by the drug, as analyzed by immunostaining with anti-actin antibodies. See Materials and Methods for details. Scale bar, $5 \mu$.

phosphorylation state of tyrosine, serine, and threonine residues in proteins from untreated and cross-linked OLs.

After cross-linking, two proteins present in the detergentinsoluble material became either tyrosine phosphorylated $(\sim 160$ $\mathrm{kDa})$ (Fig. 7A) or dephosphorylated (50 kDa) [(Fig. 7A) nonreducing gel]; these changes in phosphorylation were not found in the detergent-soluble material (data not shown). The $\sim 160 \mathrm{kDa}$ phosphotyrosine band was present in both the light and heavy fractions during floating on sucrose gradients; in contrast, the $\sim 50 \mathrm{kDa}$ dephosphorylated protein was exclusively in the light fraction (Fig. 5A) (and data not shown). These changes in phosphorylation were not found when cells were treated with antiMOG without secondary Ab (data not shown), and they were prevented if cells were pretreated with either a general tyrosine kinase (PD166285) (Fig. 7A) or phosphatase (vanadate) inhibitor (data not shown).
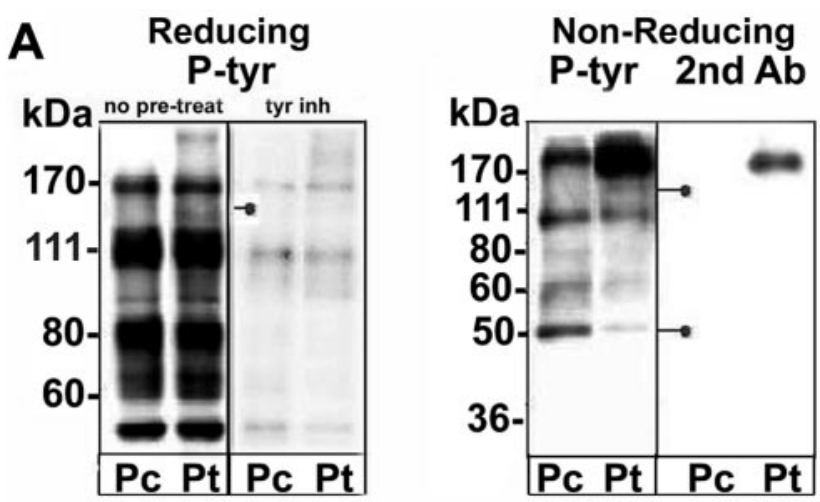

B
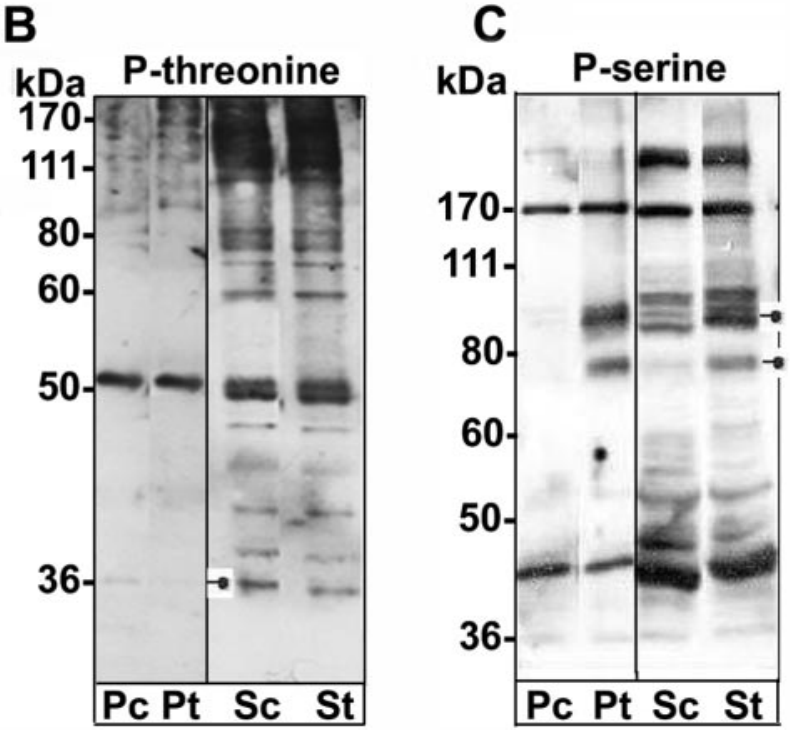

Figure 7. Altered protein phosphorylation mediated by MOG cross-linking. The soluble and insoluble fractions from TX-100 extractions $\left(4^{\circ} \mathrm{C} ; 20 \mu \mathrm{g}\right.$ of total cell protein was extracted and the entire protein yield in each fraction was loaded) of untreated control and antibody-treated [anti-MOG mAb 8-15C5 (1:100, $5 \mathrm{~min})$, anti-mouse lgG (1:500, $5 \mathrm{~min})$ ] OLs in culture were analyzed by Western blot for protein phosphorylation. $\mathrm{P}$, Insoluble pellet fraction; $\mathrm{S}$, soluble fraction; $c$, control; $t$, treated to achieve cross-linking. The positions on the gels of proteins for which the phosphorylation pattern was altered by cross-linking are indicated by closed circles attached to short lines. Typical results from three independent experiments are shown. $A$, Western blots for proteins containing phosphotyrosine were analyzed by either reducing or nonreducing gel electrophoresis. The nonreducing gels were performed to demonstrate that the $\sim 50 \mathrm{kDa}$ protein (weakly present in reducing gels, but not shown in $A$ ) was not residual antibody heavy chain. In some cases the cells were pretreated for $3 \mathrm{hr}$ with $0.1 \mu \mathrm{M}$ PD166285, a general tyrosine kinase inhibitor $(A)$. A protein of $\sim 160 \mathrm{kDa}$ was detected that became phosphorylated during MOG cross-linking. A second phosphoprotein of $\sim 50 \mathrm{kDa}$ was identified that became dephosphorylated during cross-linking. $B$, Western blot for proteins containing phosphothreonine. A protein of $\sim 35 \mathrm{kDa}$ was detected that became partially dephosphorylated during MOG cross-linking. C, Western blot for proteins containing phosphoserine. Two proteins ( 70 and $100 \mathrm{kDa}$ ) that became phosphorylated during MOG cross-linking were detected. The phosphorylation of the $\sim 70 \mathrm{kDa}$ protein(s) was strongly upregulated in both the soluble and insoluble fractions. The phosphorylation of the $\sim 100 \mathrm{kDa}$ protein(s) was strongly upregulated in the insoluble fraction and significantly so in the soluble fraction. Examples of potentially altered phosphorylation states in other proteins were tentatively identified but are not indicated.

Analyses with anti-phosphothreonine antibody identified a protein that in the insoluble fraction $\left(\mathrm{TX}-100,4^{\circ} \mathrm{C}\right)$ became dephosphorylated during cross-linking $(\sim 35 \mathrm{kDa})$. This protein has characteristics of a raft-associated protein (insoluble in TX100 at $4^{\circ} \mathrm{C}$, recovered at low density in sucrose gradients, soluble in TX-100 at $37^{\circ} \mathrm{C}$ or at $4^{\circ} \mathrm{C}$ after cholesterol extraction) (Fig. $7 \mathrm{~B}$ ) 


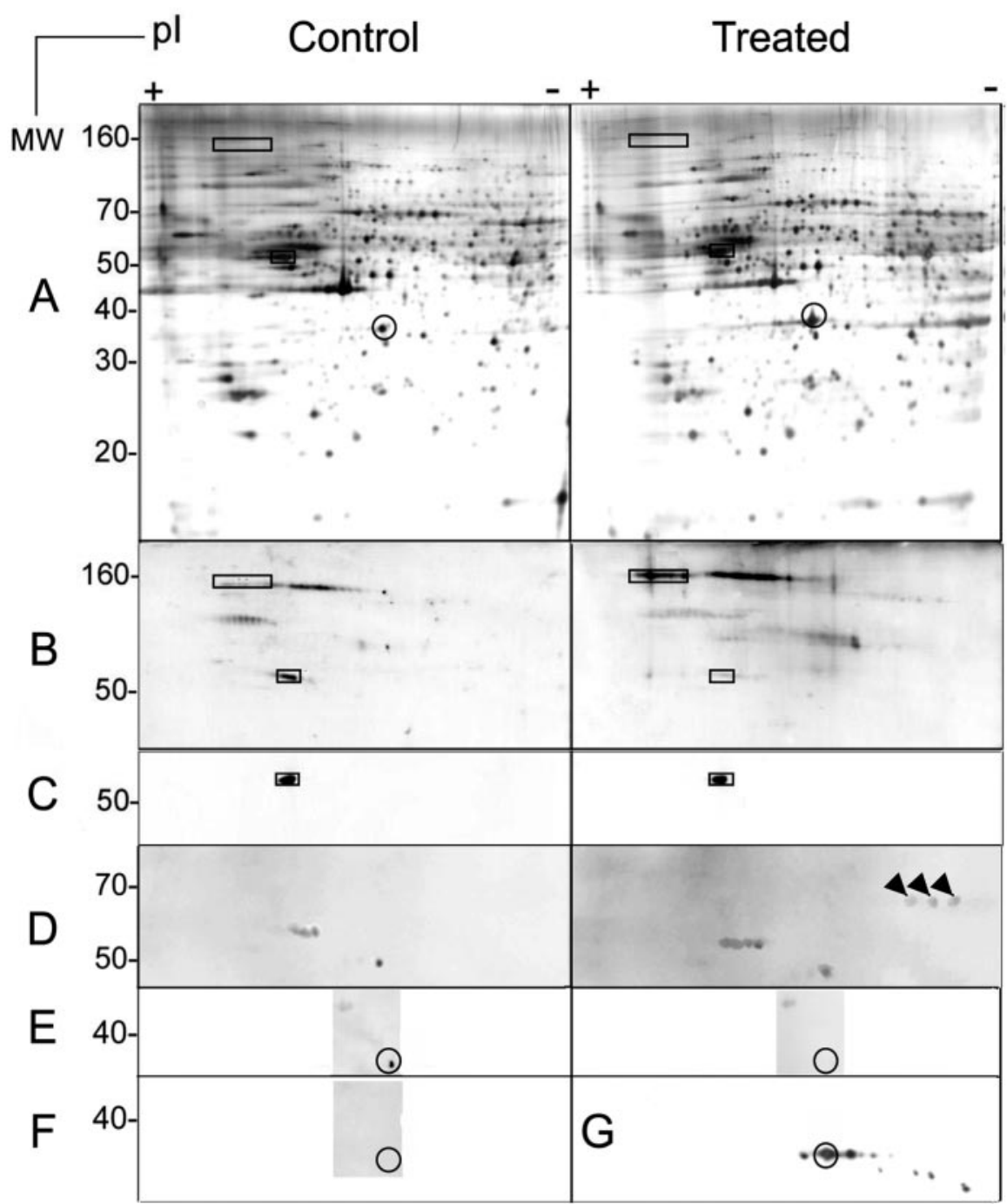

Figure 8. Two-dimensional PAGE profiles of $\mathrm{OL}$ proteins before and after MOG cross-linking. Cell lysates ( $300 \mu \mathrm{g}$ of total cell protein) from untreated and antibody-treated [anti-MOG mAb 8-15C5 (1:100, $5 \mathrm{~min})$, anti-mouse lgG (1:500, $5 \mathrm{~min})$ ] $0 \mathrm{Ls}$ in culture were analyzed by two-dimensional electrophoresis. After cross-linking, the cells were harvested by scraping into collection buffer (25 mm Tris-HCl, pH 7.5, 2\% CHAPS, 1 mu PMSF, $10 \mu \mathrm{g} / \mathrm{ml} \mathrm{leupeptin-aprotinin,} 50 \mathrm{~mm} \mathrm{NaF}, 10 \mathrm{~mm} \mathrm{NaP} 20_{7}$, and $1 \mathrm{~mm} \mathrm{Na}$ 0 -vanadate). Proteins were then precipitated with 2 vol of ethanol at $-20^{\circ} \mathrm{C}$ and resolubilized into rehydration buffer (see Materials and Methods). Typical results from three independent experiments are shown. A, Silver staining. No significant differences in the patterns of proteins from control and treated cells were noted. B. Anti-phosphotyrosine. Two proteins of $\sim 160 \mathrm{kDa} / \mathrm{pl}$ $\sim 4.5$ and $\sim 70 \mathrm{kDa} / \mathrm{pl} \sim 6$ were identified that became tyrosine phosphorylated, and one phosphotyrosine protein of $\sim 50$ $\mathrm{kDa} / \mathrm{pl} \sim 5$ was identified that became dephosphorylated, during MOG cross-linking. C, Anti- $\beta$-tubulin. The $\sim 50 \mathrm{kDa} / \mathrm{pl} \sim 5$ phosphotyrosine protein that became dephosphorylated during MOG cross-linking $(A, B)$ is identified as $\beta$-tubulin (confirmed by mass spectroscopy). $D$, Anti-phosphoserine. A triplet of proteins of $\sim 70 \mathrm{kDa} / \mathrm{pl} \sim 6.5$ became further serine phosphorylated; their identity is currently unresolved. E, Anti-phosphothreonine. A phosphothreonine protein of $\sim 35 \mathrm{kDa} / \mathrm{pl} \sim 6$ becomes dephosphorylated during MOG cross-linking. $F$, Anti-phosphothreonine pretreated with a 50-fold excess of phosphothreonine to control for the specificity of the antibody. G, Anti-G $\beta$ subunit of the trimeric G-protein. The $\sim 35 \mathrm{kDa} / \mathrm{pl} \sim 6$ phosphothreonine protein that becomes dephosphorylated during MOG cross-linking $(E)$ is identified as the $\beta$-subunit of the heterotrimeric $G$-protein complex (initially identified by mass spectrometry). Squares indicate proteins for which the tyrosine phosphorylation pattern is altered during MOG cross-linking $(A-C)$. Arrowheads indicate the triplet of serine-phosphorylated proteins $(D)$, and circles indicate threonine-dephosphorylated $G \beta$ subunit $(A, E, F, G)$ after MOG cross-linking.

(and data not shown). Analyses with anti-phosphoserine in Western blots revealed the appearance during cross-linking of at least two phosphoserine proteins $(\sim 70$ and $\sim 100 \mathrm{kDa})$ (Fig. $7 C$ ).

Levels of phospho-fyn, FAK (focal adhesion kinase), and MAPK (mitogen-activated protein kinase) were not changed after MOG cross-linking (data not shown).

We next attempted to identify proteins that change their phosphorylation status during MOG cross-linking by two-dimensional PAGE, analyzed by silver staining and Western blot with anti-phosphotyrosine, antiphosphoserine, or anti-phosphothreonine antibodies. A similar pattern of proteins (silver-stained gels) was observed in control and cross-linked cells, indicating that the overall protein content and profile were not changed during MOG cross-linking (Fig. $8 A$ ). Phosphotyrosine Western blots of MOG cross-linked samples again detected the newly phosphorylated $\sim 160 \mathrm{kDa}$ and the dephosphorylated $\sim 50 \mathrm{kDa}$ proteins (Fig. $8 B$ ). The $\sim 50 \mathrm{kDa}$ tyrosine dephosphorylated protein was identified by mass spectrometry and confirmed by Western blot analysis to be $\beta$-tubulin (Fig. $8 C$ ). The relatively low abundance of the $\sim 160 \mathrm{kDa}$ protein precluded its identification by mass spectrometry. Phosphoserine Western blots of MOG cross-linked samples resolved the newly phosphorylated $(\sim 70 \mathrm{kDa})$ protein observed on one-dimensional PAGE gels (Fig. 7C) into three proteins with different isoelectric points (Fig. 8D). Phosphothreonine Western blot analysis (Fig. 8E,F) detected the newly dephosphorylated $\sim 35$ $\mathrm{kDa}$ protein, identified by mass spectrometry and confirmed by Western blot analysis to be the $\beta(1-2)$ subunit of the heterotrimeric G-protein complex.

We conclude that cross-linking MOG on the surface of differentiated OLs growing in culture leads to the phosphorylation-dephosphorylation of tyrosine, serine, or threonine residues in specific proteins.

\section{MOG cross-linking in the presence of tyrosine kinase or serine-threonine phosphatase inhibitors}

The redistribution of MOG into the pellet (TX-100, $4^{\circ} \mathrm{C}$ ) after MOG cross-linking was not affected by pretreatment of OLs with the general tyrosine kinase inhibitor PD166285, the serine-threonine phosphatase inhibitor okadaic acid (Fig. 9A), or the general phosphatase inhibitor vanadate (data not shown). This suggests that the observed phosphorylation changes elicited by these activities are a consequence, rather than the cause, of MOG redistribution.

\section{Morphological alterations in OLs after MOG cross-linking}

Tubulin dephosphorylation in neurons is associated with growth cone collapse (Atashi et al., 1992). Therefore, the effect of crosslinking MOG and the accompanying tubulin dephosphorylation on the extension and integrity of OL processes (identified by $\mathrm{O} 4$ antibody staining, a marker for OLs) was examined (Fig. 9B, C). After MOG cross-linking (anti-MOG mAb 1:100, 5 or 15 min, and then anti-mouse IgG 1:500, 5 or $15 \mathrm{~min}$ ), mature OLs under- 

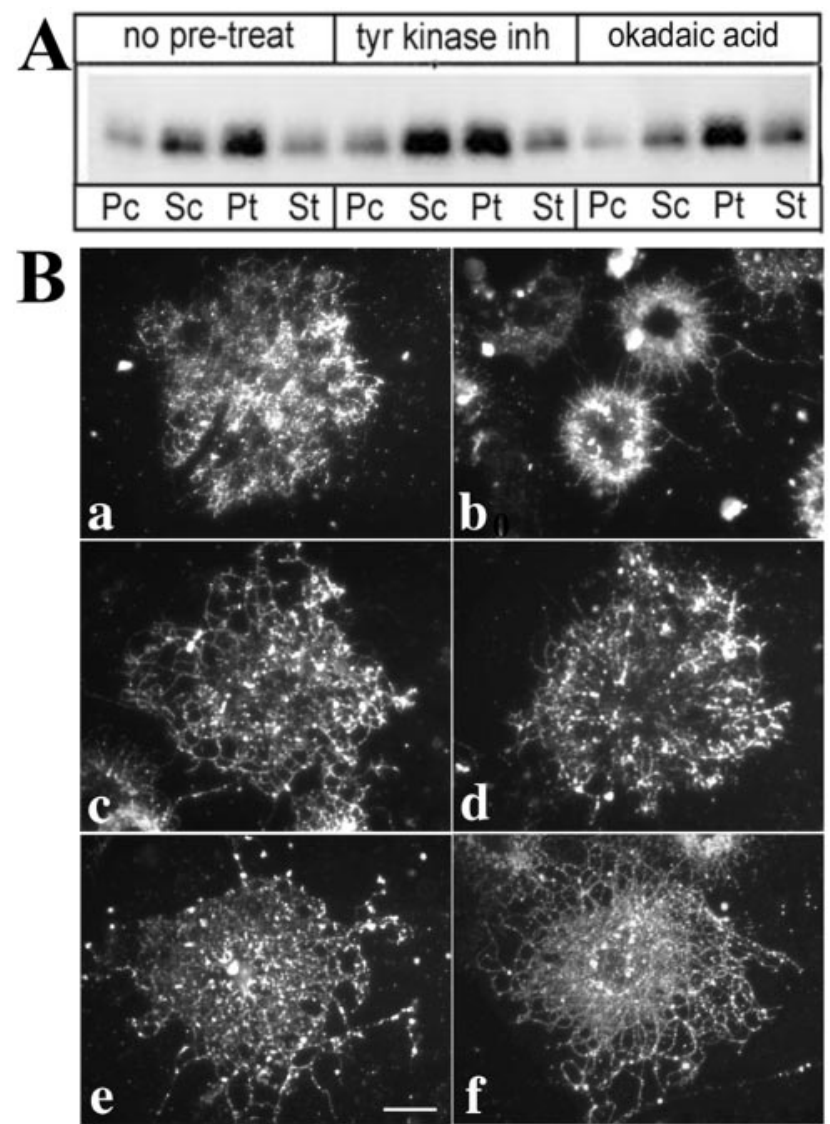

C

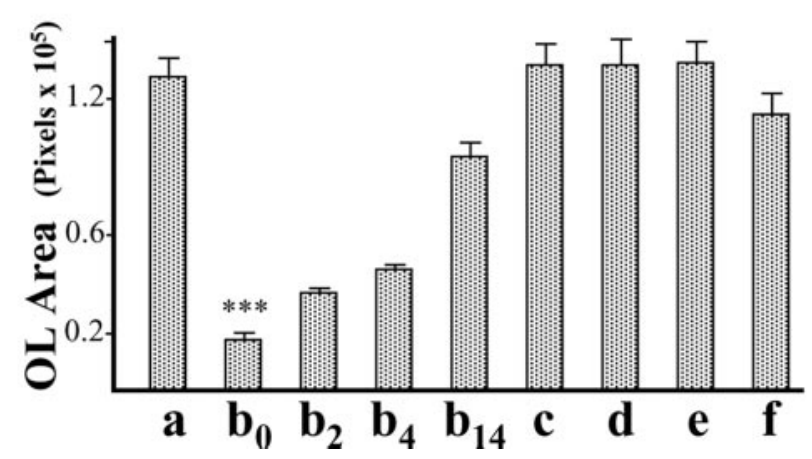

Figure 9. Changes in $0 \mathrm{~L}$ morphology during cross-linking of MOG. OLs in culture were either left untreated as controls (see Materials and Methods) or antibody treated [anti-MOG mAb $8-15 C 5$ (1:100, $5 \mathrm{~min})$, anti-mouse $\lg G(1: 500,5 \mathrm{~min})]$. A, Cell lysates were extracted with TX-100 ( $4^{\circ} \mathrm{C} ; 20 \mu \mathrm{g}$ total cellular protein) and separated into insoluble (P) and soluble (S) fractions by centrifugation, and the entire protein yield of the fractions was analyzed for MOG by Western blotting. c, Control; t, treated to achieve cross-linking. Pretreatment with either a tyrosine kinase (PD166285) or a serine-threonine phosphatase (okadaic acid) inhibitor did not affect the repartitioning of MOG into the insoluble fraction. $B$, Cells were immunostained with 04 antibody for epifluorescence microscopy. Scale bar, $5 \mu$. C, The areas occupied by randomly chosen cells were calculated by measuring the number of pixels per cell using Adobe Photoshop 5.0. $B, C$, Lowercase letters ( $a, c, e)$ : no anti-MOG cross-linking; (b, d, f): anti-MOG cross-linked; $\left(a, b_{0}\right)$ : no further treatment; $\left(b_{2}, b_{4}, b_{14}\right)$ : the antibody-containing medium was removed, and the cells were grown further in fresh medium for $2\left(b_{2}\right), 4\left(b_{4}\right)$, or $14 \mathrm{hr}\left(b_{14}\right) . c, d$, Pretreatment for $3 \mathrm{hr}$ with $0.1 \mu \mathrm{m}$ PD166285, a tyrosine kinase inhibitor; e, f, pretreatment for $3 \mathrm{hr}$ with $10 \mathrm{~nm}$ okadaic acid, a serine-threonine phosphatase inhibitor. $* * *, a / b_{0}$, and $\mathrm{b}_{0} / \mathrm{b}_{14}$ indicate statistically significant differences, $p \leq 0.0001$; the values of $a, c-f$, and $b_{0}, b_{2}$, and $b_{4}$ are not significantly different $(p>0.5)$. Error bars represent SEM; $n=20-35$. Note that inhibition of phosphorylation or dephosphorylation did not alter the antibody-mediated repartitioning of MOG but did block the changes in morphology observed during MOG cross-linking of uninhibited cells. The effect of MOG cross-linking on OL morphology was reversible.
A

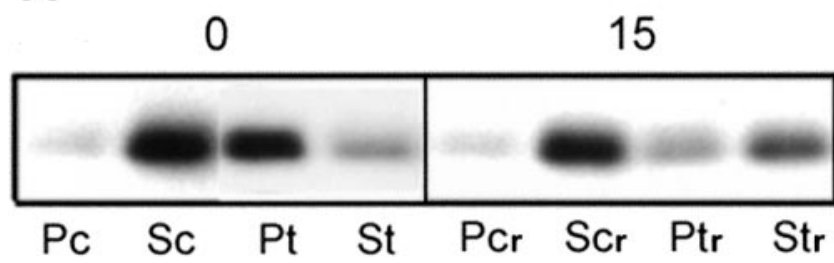

B

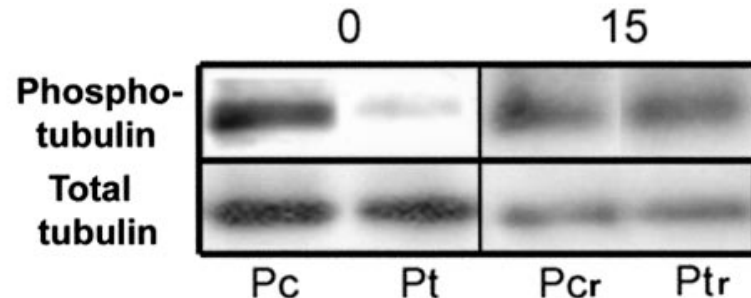

Figure 10. Reversibility of MOG repartitioning and tubulin dephosphorylation. OLs in culture were first either left untreated as controls (Pc, Sc) or antibody-treated [Pt, St; anti-MOG mAb 8-15C5 (1:100, $5 \mathrm{~min})$, anti-mouse lgG (1:500, $5 \mathrm{~min})]$. The control and antibodycontaining media were then removed, and the cells were grown further in fresh medium ( $\mathrm{Pcr}$, Ptr) for $15 \mathrm{~min}$. Cell lysate (20 $\mu \mathrm{g}$ of protein) was extracted with $\mathrm{TX}-100\left(4^{\circ} \mathrm{C}\right)$ and separated into soluble $(S)$ and insoluble $(P)$ fractions by centrifugation, and the entire yield in each fraction was loaded in the gels for each condition and analyzed by Western blot. Typical results from three independent experiments are shown. $A$, Anti-MOG; $B$, anti- $\beta$-tubulin (phosphotubulin and total tubulin). Immediately after cross-linking followed by removal of the antibody ( $0 ; \mathrm{Pt}$, $S t$ ), as expected (above), nearly all MOG is recovered in the insoluble (P) fraction $(A)$, and nearly all $\beta$-tubulin is dephosphorylated $(B)$. However, within 15 min after removal of the antibody (15; Ptr, Str), nearly all MOG is now recovered once again in the soluble fraction (Str), and $\beta$-tubulin has become rephosphorylated to a level nearly equal to that of untreated controls.

went dramatic retraction of cell processes and membrane sheets, with a consequent reduction in the area occupied by the OLs (Fig. 9 , compare $\left.a, b_{0},\right)(p<0.0001)$. These changes in morphology were not observed in OLs treated with anti-MOG antibody alone (no cross-linking with secondary antibody), and they were prevented entirely if OLs were treated with either a general tyrosine kinase inhibitor (PD166285) (Fig. 9c,d) or a serine-threonine phosphatase inhibitor (okadaic acid) (Fig. $9 e, f$ ) before and during MOG cross-linking. Essentially identical results were obtained when the immunocytochemical analyses were performed using antiserum against myelin basic protein (MBP), marker of mature OLs, to estimate the areas occupied by OLs (data not shown). We conclude that MOG cross-linking leads to a reversible retraction of myelin-like membranes and processes as the result of alterations in phosphorylation of signal transduction and cytoskeletal proteins. The potential significance of these changes for demyelinating disease is intriguing.

\section{Reversibility of MOG cross-linking}

To assess the reversibility of MOG cross-linking-mediated events, the antibody was removed, and the cells were refed with fresh medium and further incubated at $37^{\circ} \mathrm{C}$. Within $15 \mathrm{~min}$ both the amount of MOG that was insoluble in TX-100 at $4^{\circ} \mathrm{C}$ and the level of phosphorylation of $\beta$-tubulin returned nearly to levels observed in untreated control cells (Fig. 10 A,B) (after $30 \mathrm{~min}$, only a very small amount of MOG was still present in the detergent-soluble fraction; data not shown). These results indicate that MOG repartitioning and $\beta$-tubulin dephosphorylation after MOG cross-linking in OLs is rapidly reversible and that $\beta$-tubulin dephosphorylation is observed only when a significant amount of MOG is present in the insoluble fraction. Similarly, 
reversibility occurred with regard to cross-linking-induced changes in morphology. When the antibody-containing medium was removed and the cells were further incubated with fresh culture medium at $37^{\circ} \mathrm{C}$, within $2-4 \mathrm{hr}$ the treated OLs began to re-extend processes and increase their occupied area and underwent substantial recovery of process extension (to $>75 \%$ of control cultures) within $14 \mathrm{hr}$ of incubation (Fig. 9C, $\mathrm{b}_{0}, \mathrm{~b}_{2}, \mathrm{~b}_{4}, \mathrm{~b}_{14}$ ). Thus, morphological recovery, albeit substantial, is a slower event than the return to control levels of MOG partitioning and phosphorylation states.

\section{Discussion}

Cross-linking of membrane proteins is a physiological phenomenon that can lead to the repartitioning of these proteins into lipid rafts, resulting in novel protein interactions and initiation of cell signaling (Simons and Toomre, 2000; Ikonen, 2001). Although occurring naturally via multivalent ligands, similar responses have been observed using antibodies (Simons and Toomre, 2000).

In this report we show that although MOG in OLs in culture is mostly detergent soluble (TX-100, $4^{\circ} \mathrm{C}$ ), it becomes repartitioned into a detergent-insoluble fraction during antibody-induced crosslinking (anti-MOG + secondary antibody). Concomitantly, there is an upregulation of the phosphorylation or dephosphorylation of tyrosine, serine, or threonine residues in specific proteins, accompanied by a dramatic retraction of myelin-like membrane sheets and cellular processes. These observations are consistent with a model proposing that during MOG-cross-linking, specific signal transduction pathways are activated, resulting in alterations in the maintenance of OL cell processes and myelin-like membrane. This repartitioning of MOG is rapid ( $\leq 1 \mathrm{~min}$ ) and reversible and occurs at concentrations of antibody substantially lower than previously used to perturb OLs in culture (Dyer and Matthieu, 1994). After the detergent-insoluble fraction is floated on sucrose gradients, MOG is distributed between light- and heavy-density fractions. The lowdensity fraction has characteristics of lipid rafts; these include, in addition to its low density, sensitivity to pretreatment with cholesterol perturbing agents before detergent extraction (TX-100, $4^{\circ} \mathrm{C}$ ) that renders MOG soluble. The heavy-density fraction is enriched in the cytoskeletal proteins $\beta$-tubulin and $\beta$-actin, suggesting that protein-protein interactions are involved.

After MOG cross-linking there are specific changes in the phosphorylation of tyrosine, serine, and threonine residues of specific detergent-insoluble proteins that are associated with rafts, including $\beta$-tubulin and $G \beta 1-2$. We propose that there is a causal relationship between partitioning of MOG into the detergent-insoluble fractions and the induced phosphorylationdephosphorylation events. Although the partitioning of MOG is independent of cellular tyrosine kinase or serine-threonine phosphatase activities, the retraction of cell processes requires the changes in phosphorylation state. Therefore, we speculate a sequence of events in which MOG cross-linking induces repartitioning, implementing novel protein-protein interactions within lipid rafts, followed in turn by specific changes in protein phosphorylation state, resulting in cellular morphological alterations.

Moreover, this study, as well as others (Holowka et al., 2000; Fassett et al., 2001; Nebl et al., 2002), indicates that raft integrity depends on intact microtubules and microfilaments. Consistent with this, although the bulk of tubulin and actin were found in the heavy detergent-soluble fraction, significant levels of these proteins were also identified in the low-density lipid raft fraction, suggesting a close relationship between cytoskeletal elements and rafts (Holowka et al., 2000; Maekawa et al., 2001; this study). This is strongly supported by our observation that disruption of the cytoskeleton leads to a concomitant disruption of the OL lipid rafts, as indicated by the redistribution of raft markers (e.g., caveolin) from the detergent-insoluble light fraction to the heavy fraction.

The identification of proteins that change their phosphorylation status after MOG cross-linking is a key step toward identifying mechanisms leading to altered cell physiology. In particular, we identified the dephosphorylation of $\beta$-tubulin and G-protein $\beta$ subunit. $\beta$-tubulin dephosphorylation affects microtubule polymerization (Atashi et al., 1992) and is likely to be a factor in the loss of OL membrane reported in this study (acute anti-MOG exposure) and by Dyer and Matthieu (1994) (chronic anti-MOG exposure). The G-protein $\beta \gamma$ complex regulates the activity of a diverse set of effectors, including phospholipases, adenyl cyclases, and ion channels (Clapham and Neer, 1997). Phosphorylation of the $\beta$ subunit activates the dissociated G $\beta \gamma$ complex (Sternweis, 1994; Nürnberg et al., 1996). The dephosphorylation of $G \beta \gamma$ complex could therefore affect a number of different downstream signaling pathways.

MOG is clearly implicated in demyelinating disease. Immunological studies in humans also identified MOG as a prevalent antigenic molecule among the myelin proteins (Von Büdingen et al., 2001). The encephalitogenic properties of MOG are mainly linked to the induction of antibody responses, which directly promote demyelination in CNS disorders such as MS. Although autoimmune responses directed against CNS antigens have generally been considered pathogenic, some reports show that both cellular and humoral immune responses can promote tissue repair after CNS injury and disease. In particular, the exciting observation that some polyreactive IgM autoantibodies reacting with OL surface antigens (not well characterized yet) promote myelin repair (Warrington et al., 2000; Bieber et al., 2001, 2002), as well as the previous finding that the IgM antibody O4 (against sulfogalactolipids) enhances OL differentiation (Bansal et al., 1988), suggests their possible application as therapeutic agents.

In rat and marmoset models, MOG-induced EAE demyelination is anti-MOG antibody dependent and reproduces the immunopathology seen in many cases of MS. The demyelinating activity of MOG-specific antibody has often been related to its ability to activate complement, which could compromise the metabolic integrity of the cell and/or directly kill OLs and thus disrupt myelin (Piddlesden et al., 1993; for review, see Iglesias et al., 2001; Von Büdingen et al., 2001). The finding that purified MOG binds C1q (Johns and Bernard, 1997) strengthens this hypothesis. However, MBP degradation and membrane loss leading to anti-MOG-induced demyelination was also found in models independent of complement action (Dyer and Matthieu, 1994; Menon et al., 1997; this report).

We propose a new, complement-independent model for MOG/anti-MOG-induced demyelination. According to this model, elevated titers of anti-MOG antibody lead to a sequence of events: (1) cross-linking of MOG results in the repartitioning of a large fraction of MOG into DIGs; (2) MOG forms complexes with specific protein partners (e.g., kinases and phosphatases) that are in DIGs; (3) specific signaling pathways become activated; (4) alterations of OL physiology critical for membrane maintenance are elicited. We propose further that similar events may occur in MS. Several questions need to be addressed, including whether antibody cross-linking is mimicking or exacerbating, or both, the action of an endogenous ligand, in which case this signaling could be related not only to anti-MOG-induced demyelination but also to normal MOG function within the OLs. 


\section{References}

Abrami 1, Fivaz M, Kobayashi T, Kinoshita T, Parton R, Van der Goot FG (2001) Cross-talk between caveolae and glycosylphosphatidylinositolrich domains. J Biol Chem 276:30729-30736.

Atashi JR, Klinz SG, Ingraham CA, Matten WT, Schachner M, Maness S (1992) Neural cell adhesion molecules modulate tyrosine phosphorylation of tubulin in nerve growth cone membranes. Neuron 8:831-842.

Bansal R, Pfeiffer SE (1985) Developmental expression of 2', $3^{\prime}$-cyclic nucleotide $3^{\prime}$-phosphohydrolase in dissociated fetal rat brain cultures and rat brain. J Neurosci Res 14:21-34.

Bansal R, Pfeiffer SE (1989) Reversible inhibition of oligodendrocyte progenitor differentiation by a monoclonal antibody against surface galactolipids. Proc Natl Acad Sci USA 86:6181-6185.

Bansal R, Gard AL, Pfeiffer SE (1988) Stimulation of oligodendrocyte differentiation in culture by growth in the presence of a monoclonal antibody to sulfated glycolipid. J Neurosci Res 21:260-267.

Bansal R, Warrington AE, Gard AL, Ranscht B, Pfeiffer SE (1989) Multiple and novel specificities of monoclonal antibodies $\mathrm{O} 1, \mathrm{O} 4$, and $\mathrm{R}-\mathrm{mAb}$ used in the analysis of oligodendrocyte development. J Neurosci Res 24:548-557.

Bansal R, Kumar M, Murray K, Morrison RS, Pfeiffer SE (1996) Regulation of FGF receptors in the oligodendrocyte lineage. Mol Cell Neurosci 7:263-275.

Bansal R, Winkler S, Bheddah S (1999) Negative regulation of oligodendrocyte differentiation by galactolipids. J Neurosci 19:7913-7924.

Bieber AJ, Warrington A, Pease LR, Rodriguez M (2001) Humoral autoimmunity as a mediator of CNS repair. Trends Neurosci [Suppl] 24:S39-44.

Bieber AJ, Warrington A, Asakura K, Ciric B, Kaveri SV, Pease L, Rodriguez M (2002) Human antibodies accelerate the rate of remyelination following lysolecithin-induced demyelination in mice. Glia 37:241-249.

Bottenstein J, Sato G (1979) Growth of a rat neuroblastoma line in serumfree supplemented medium. Proc Natl Acad Sci USA 76:514-517.

Brown DA, London E (1998) Structure and origin of ordered lipid domains in biological membranes. J Membr Biol 164:103-114.

Brown DA, Rose JK (1992) Sorting of GPI-anchored proteins to glycolipidenriched membrane subdomains during transport to the apical cell surface. Cell 68:533-544.

Cerneus D, Ueffing E, Posthuma G, Strous G, Van der Ende A (1993) Detergent insolubility of alkaline phosphatase during biosynthetic transport and endocytosis. J Biol Chem 268:3150-3155.

Clapham DE, Neer EJ (1997) G protein beta gamma subunits. Annu Rev Pharmacol Toxicol 37:167-203.

De Angelis DA, Braun PE (1996) 2',3'-cyclic nucleotide 3'-phosphodiesterase binds to actin-based cytoskeletal elements in an isoprenylationindependent manner. J Neurochem 67:943-951.

Dyer CA, Matthieu JM (1994) Antibodies to myelin/oligodendrocytespecific protein and myelin/oligodendrocyte glycoprotein signal distinct changes in the organization of cultured oligodendroglial membrane sheets. J Neurochem 62:777-787.

Fassett MS, Davis DM, Valter MM, Cohen GB, Strominger JL (2001) Signaling at the inhibitory natural killer cell immune synapse regulates lipid raft polarization but not class I MHC clustering. Proc Natl Acad Sci USA 98:14547-14552.

Friedrichson T, Kurzchalia TV (1998) Microdomains of GPI-anchored proteins in living cells revealed by crosslinking. Nature 394:802-805.

Gard AL, Pfeiffer SE (1989) Oligodendrocyte progenitors isolated directly from developing telencephalon at a specific phenotypic stage: myelinogenic potential in a defined environment. Development 106:119-132.

Genain CP, Cannella B, Hauser SL, Raine CS (1995) Identification of autoantibodies associated with myelin damage in multiple sclerosis. Nat Med 5:170-175.

Hanada K, Nishijima M, Akamatsu Y, Pagano R (1995) Both sphingolipids and cholesterol participate in the detergent insolubility of alkaline phosphatase, a glycosylphosphatidylinositol-anchored protein in mammalian membranes. J Biol Chem 270:6254-6260.

Holowka D, Sheets ED, Baird B (2000) Interactions between Fc(epsilon)RI and lipid raft components are regulated by the actin cytoskeleton. J Cell Sci 113:1009-1019.

Iglesias A, Bauer J, Litzenburger T, Schubart A, Linington C (2001) T- and $\mathrm{B}$-cell responses to myelin oligodendrocyte glycoprotein in experimental autoimmune encephalomyelitis and multiple sclerosis. Glia 36:220-234.
Ikonen E (2001) Roles of lipid rafts in membrane transport. Curr Opin Cell Biol 13:470-477.

Johns TG, Bernard CA (1997) Binding of component C1q to myelin oligodendrocyte glycoprotein: a novel mechanism for regulating CNS inflammation. Mol Immunol 34:33-38.

Johns TG, Bernard CA (1999) The structure and function of myelin oligodendrocyte glycoprotein. J Neurochem 72:1-9.

Jung M, Sommer I, Schachner M, Nave KA (1996) Monoclonal antibody O10 defines a conformationally sensitive cell-surface epitope of proteolipid protein (PLP): evidence that PLP misfolding underlies dysmyelination in mutant mice. J Neurosci 16:7920-7929.

Kerlero de Kosbo N, Honegger P, Lassmann H, Matthieu JM (1990) Demyelination induced in aggregating brain cell cultures by a monoclonal antibody against myelin/oligodendrocyte glycoprotein. J Neurochem 55:583-587.

Kim T, Pfeiffer SE (1999) Myelin glycosphingolipid/cholesterol-enriched microdomains selectively sequester the non-compact myelin proteins CNP and MOG. J Neurocytol 28:281-293.

Kim T, Fieldler K, Madison DL, Krueger WH, Pfeiffer SE (1995) Cloning and characterization of MVP-17: a developmentally regulated myelin protein in oligodendrocytes. J Neurosci Res 42:413-422.

Kramer EM, Koch T, Niehaus A, Trotter J (1997) Oligodendrocytes direct glycosyl phosphatidylinositol-anchored proteins to the myelin sheath in glycosphingolipid-rich complexes. J Biol Chem 272:8937-8945.

Kramer EM, Klein C, Koch T, Boytinck M, Trotter J (1999) Compartmentation of Fyn kinase with glycosylphosphatidylinositol-anchored molecules in oligodendrocytes facilitates kinase activation during myelination. J Biol Chem 274:29042-29049.

Ledesma MD, Simons K, Dotti CG (1998) Neuronal polarity: essential role of protein-lipid complexes in axonal sorting. Proc Natl Acad Sci USA 95:3966-3971.

Linington C, Lassmann H (1987) Antibody responses in chronic relapsing experimental allergic encephalomyelitis: correlation of serum demyelinating activity with antibody titre to the myelin/oligodendrocyte glycoprotein (MOG). J Neuroimmunol 17:61-69.

Linington C, Webb M, Woodhams PL (1984) A novel myelin-associated glycoprotein defined by a mouse monoclonal antibody. J Neuroimmunol 6:387-396.

Linington C, Bradl M, Lassmann H, Brunner C, Vass K (1988) Augmentation of demyelination in rat acute allergic encephalomyelitis by circulating mouse monoclonal antibodies directed against a myelin/oligodendrocyte glycoprotein. Am J Pathol 130:443-454.

Madison DL, Krueger WH, Cheng D, Trapp BD, Pfeiffer SE (1999) SNARE complex proteins, including the cognate pair VAMP-2 and syntaxin-4, are expressed in cultured oligodendrocytes. J Neurochem 72:988-998.

Maekawa S, Morii H, Kumanogoh H, Sano M, Naruse Y, Sokawa Y, Mori N (2001) Localization of neuronal growth-associated, microtubuledestabilizing factor SCG10 in brain-derived raft membrane microdomains. J Neurochem (Tokyo) 129:691-697.

Menon K, Piddlesden SJ, Bernard CCA (1997) Demyelinating antibodies to myelin oligodendrocyte glycoprotein and galactocerebroside induce degradation of myelin basic protein in isolated human myelin. J Neurochem 69:214-222.

Nebl T, Pestonjamasp KN, Leszyk JD, Crowley JL, Oh SW, Luna EJ (2002) Proteomic analysis of a detergent-resistant membrane skeleton from neutrophil plasma membranes. J Biol Chem 277:43399-43409.

Nürnberg B, Harhammer R, Exner T, Schulze RA, Wieland T (1996) Species- and tissue-dependent diversity of G-protein $\beta$ subunit phosphorylation: evidence for a cofactor. Biochem J 318:717-722.

Pereyra PM, Horvath E, Braun PE (1988) Triton X-100 extractions of central nervous system myelin indicate a possible role for the minor myelin proteins in the stability in lamellae. Neurochem Res 13:583-595.

Pfeiffer SE, Warrington AE, Bansal R (1993) The oligodendrocyte and its many cellular processes. Trends Cell Biol 3:191-197.

Piddlesden SJ, Lassmann H, Zimprich F, Morgan BP, Linington C (1993) The demyelinating potential of antibodies to myelin oligodendrocyte glycoprotein is related to their ability to fix complement. Am J Pathol 143:555-564.

Pigino G, Pelsman A, Mori H, Busciglio J (2001) Presenilin-1 mutations reduce cytoskeletal association, deregulate neurite growth, and potentiate neuronal dystrophy and Tau phosphorylation. J Neurosci 21:834-842. 
Reindl M, Linington C, Brehm U, Egg R, Dilitz E, Deisenhammer F, Poewe V, Berger T (1999) Antibodies against the myelin oligodendrocyte glycoprotein and the myelin basic protein in multiple sclerosis and other neurological diseases: a comparative study. Brain 122:2047-2056.

Rothberg KG, Ying YS, Kamen BA, Anderson RGW (1990) Cholesterol controls the clustering of the glycophospholipid-anchored membrane receptor for 5-methyltetrahydrofolate. J Cell Biol 111:2931-2938.

Schluesener HJ, Sobel RA, Linington C, Weiner HL (1987) A monoclonal antibody against a myelin oligodendrocyte glycoprotein induces relapses and demyelination in central nervous system autoimmune disease. J Immunol 139:4016-4021.

Simons K, Ikonen E (1997) Functional rafts in cell membranes. Nature 387:569-572.

Simons K, Toomre D (2000) Lipid rafts and signal transduction. Nat Rev Mol Cell Biol 1:31-39.

Simons M, Kramer EM, Thiele C, Stoffel W, Trotter J (2000) Assembly of myelin by association of proteolipid protein with cholesterol- and galactosylceramide-rich membrane domains. J Cell Biol 151:143-154.

Singh H, Pfeiffer SE (1985) Myelin-associated galactolipids in primary cultures from dissociated fetal rat brain: synthesis, accumulation, and cell surface expression. J Neurochem 45:1371-1381.

Sommer I, Schachner M (1981) Monoclonal antibodies (O1 to O4) to oli- godendrocyte cell surfaces: an immunocytological study in the central nervous system. Dev Biol 83:311-327.

Sternweis PC (1994) The active role of beta gamma in signal transduction. Curr Opin Cell Biol 6:198-203.

Stulnig TM, Berger M, Sigmund T, Stockinger H, Horejsi V, Waldhausl W (1997) Signal transduction via glycosyl phosphatidylinositol-anchored proteins in T cells is inhibited by lowering cellular cholesterol. J Biol Chem 272:19242-19247.

Taylor CM, Coetzee T, Pfeiffer SE (2002) Detergent-insoluble glycosphingolipid/cholesterol microdomains of the myelin membrane. J Neurochem 81:993-1004.

Varma R, Mayor S (1998) GPI-anchored proteins are organized in submicron domains at the cell surface. Nature 394:798-801.

Von Büdingen HC, Tanuma N, Villoslada P, Ouallet JC, Hauser S, Genain C (2001) Immune responses against the myelin/oligodendrocyte glycoprotein in experimental autoimmune demyelination. J Clin Immunol 21:155-170.

Warrington A, Asakura K, Bieber AJ, Ciric B, Van Keulen V, Kaveri S, Kyle R, Pease L, Rodriguez M (2000) Proc Natl Acad Sci USA 97:6820-6825.

Xiao BG, Linington C, Link $\mathrm{H}$ (1991) Antibodies to myelinoligodendrocyte glycoprotein in cerebrospinal fluid from patients with multiple sclerosis and controls. J Neuroimmunol 31:91-96. 